\title{
The Sodium and Potassium Content of Non-Halophilic Bacteria in Relation to Salt Tolerance
}

\author{
By J. H. B. CHRISTIAN AND JUDITH A. WALTHO \\ Commonrealth Scientific and Industrial Research Organization, Division of \\ Food Preservation, Homebush, New South Wales, Australia
}

(Received 28 October 1960)

\begin{abstract}
SUMMARY
The sodium and potassium contents of cells of 32 strains of non-halophilic bacteria were determined after growth in a standard medium of low salt content. The salt tolerance of each strain was assessed by determining the lowest water activity at which growth occurred in sodium chloride medium. Among the strains examined the potassium contents varied about fivefold and were positively correlated with salt tolerance.
\end{abstract}

\section{INTRODUCTION}

Bacteria differ greatly in ability to grow in high concentrations of sodium chloride. The growth of some strains is prevented by 2-3\% salt, but some halophilic bacteria proliferate in media saturated with sodium chloride. These halophiles were shown by Baxter \& Gibbons (1956) to contain enzymes which were active in solutions of very high ionic strength. No explanation has been advanced for the large differences in salt tolerance found among non-halophilic bacteria.

Cells of Salmonella oranienburg respiring in concentrated solutions accumulated much more potassium than in dilute media (Christian, 1955), suggesting that potassium largely controlled the water activity $\left(a_{w}\right)$ within the cell. Further, the salmonellas are relatively intolerant of high salt concentrations or low $a_{w}$ (Christian $\&$ Scott, 1953) and contain little potassium (Barber, 1931; Christian, 1958), while the staphylococci are very salt tolerant (Maitland \& Martyn, 1948; Scott, 1953) and are very rich in potassium (Barber, 1931). The present paper presents results which support the hypothesis that salt tolerance in non-halophiles is related to ability to accumulate potassium within the cells.

\section{METHODS}

Organisms. Thirty-two strains of bacteria were studied, comprising: twelve Gram-positive cocci (Leuconostoc citrovorum; Micrococcus lysodeikticus, M. roseus; two Sarcina spp.; Staphylococcus aureus, Staph. albus, Staph. citreus; Streptococcus cremoris, Strep. faecalis, Strep. lactis and an unidentified coccus); fifteen Grampositive spore-forming rods (two Bacillus cereus, B. megaterium, B. mycoides, B. subtilis var. niger, nine unidentified strains); five Gram-negative strains (Escherichia coli, Flavobacterium sp., Pseudomonas fluorescens, Salmonella oranienburg, Vibrio metchnikovi).

Salt tolerance. Salt tolerance was determined at $\mathrm{pH} \mathbf{7 \cdot 0}$ in brain + heart infusion 
broth, sodium chloride being added to provide the desired values of $a_{w}$ in steps of 0.01 . Ten ml. volumes of medium were dispensed in $100 \mathrm{ml}$. screw-cap bottles which, after inoculation with $0.02 \mathrm{ml}$. of a $16 \mathrm{hr}$. broth culture, were incubated at $30^{\circ}$ for 28 days. The lowest $a_{w}$ value which supported growth was determined by observation of turbidity.

Ion content. For analysis, organisms were grown in $100 \mathrm{ml}$. brain theart broth $\left(0.993 a_{w}\right)$ in $250 \mathrm{ml}$. Erlenmeyer flasks shaken at $30^{\circ}$. On reaching the stationary phase of growth, each culture was centrifuged to give two equal cell pellets. One pellet was weighed before and after drying at $105^{\circ}$ (giving dry weight and water content) and the other pellet was extracted with cold trichloroacetic acid. Extracts were analysed for sodium and potassium by flame photometry.

Interstitial space was determined by phosphate dilution (Mitchell \& Moyle, 1956) in centrifugates of four Gram-positive cocci, one Gram-positive rod and one Gramnegative rod. Large differences were found, probably because of differences in packing fractions as between strains. However, when internal water was calculated from these values, the mean and standard error for the six strains was $1.50 \pm 0.03 \mathrm{ml}$./ g. dry weight. This figure was applied to all strains, and, the dry weight and total water content of the centrifugate and the water content of the medium for each preparation being known, the interstitial volume could be calculated. The supernatant fluid, and hence the interstitial medium, contained 163 m-equiv. sodium and 25 m-equiv. potassium/l. The amounts of these ions in the interstitial volume were calculated and subtracted from the values for whole pellets. These net values for sodium and potassium contents were expressed as $\mu$-equiv./100 mg. dry wt. cells. All values presented are means from at least two experiments.

\section{RESULTS}

The relationship between the potassium content of cells grown in standard medium and the lowest $a_{w}$ value which supported growth of the same strains in media adjusted with sodium chloride is shown in Fig. 1. For the thirty-two strains the correlation coefficient was $-0.89(P<0.001)$. An unidentified coccus, growing to $\mathbf{0 . 8 4} a_{w}$, was much more salt-tolerant than the staphylococci (lower limits of 0.89 to $0 \cdot 88 a_{w}$ ) yet contained no more potassium. If this organism was excluded the correlation coefficient was $-0.91(P<0.001)$. Potassium content was directly related to salt tolerance, increasing by about fivefold as the minimum $a_{w}$ supporting growth decreased from $0 \cdot 975$ to $\mathbf{0 \cdot 8 4}$.

An inverse relationship often exists between cellular contents of sodium and potassium. The increase in salt tolerance which accompanied enhanced potassium content might thus be associated with a decrease in cell sodium. This was generally the case for Gram-positive cocci and Gram-negative rods (Fig. 2a). However, at a given sodium content, the rods were less salt tolerant than the cocci. The most salttolerant coccus again behaved exceptionally. On the other hand, in Gram-positive sporing rods, sodium content increased appreciably with decrease in limiting $a_{w}$ value (Fig. $2 b$ ). The pronounced scatter of values in Fig. $2 b$ may result from uptake of sodium during harvesting and preparation for analysis. When only the lowest sodium contents recorded for each strain are plotted, the increase in sodium with decreasing $a_{w}$ value is more marked. Figure 2 shows also that some strains had internal sodium concentrations lower than in the growth medium. These strains 
were amongst the most salt-tolerant cocci and Gram-negative rods, and among the least tolerant of the Bacillus spp.

The differences between the two groups of bacteria are further demonstrated in Fig. 3, where potassium to sodium ratios are plotted as a function of the minimum $a_{w}$ value supporting growth. The steep rise in this ratio as salt tolerance increased in cocci and Gram-negative rods contrasts with its virtual constancy for Bacillus spp.

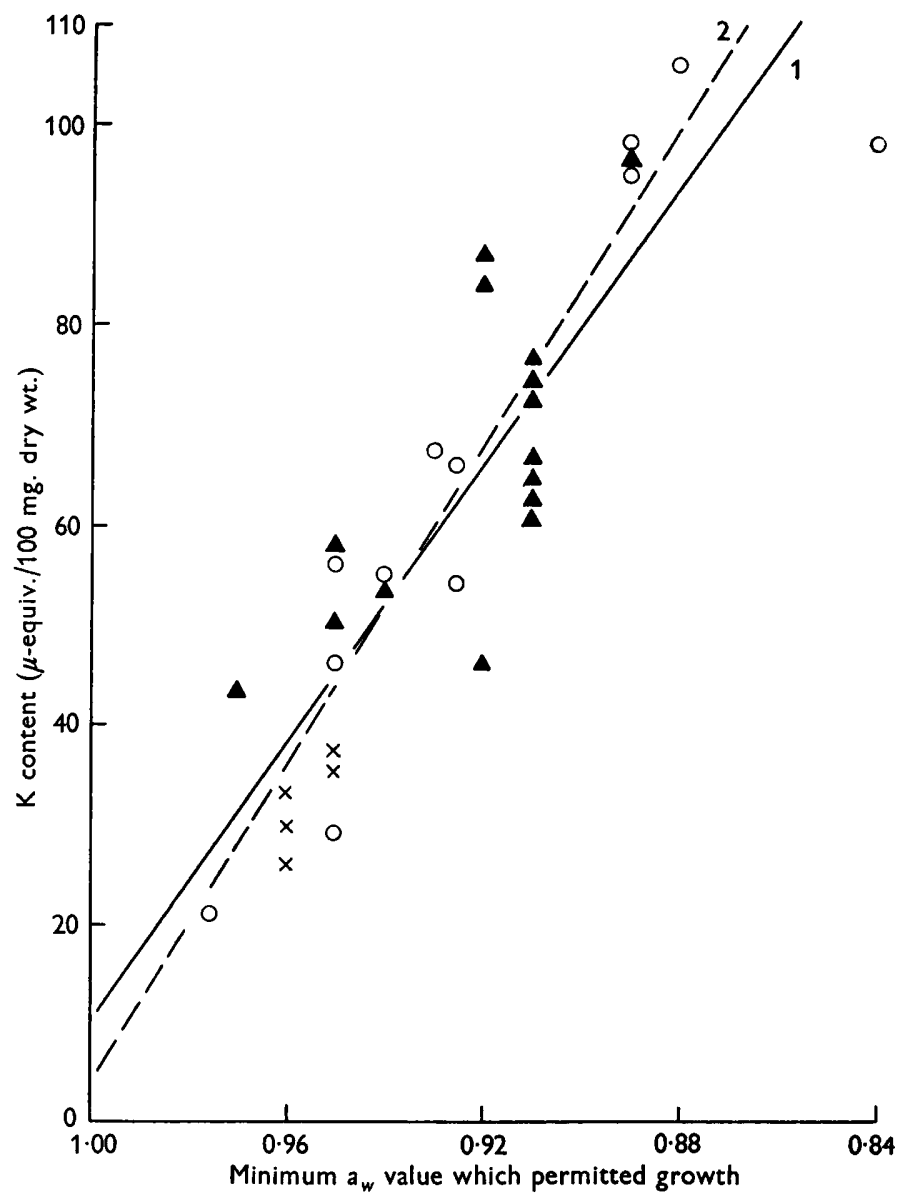

Fig. 1. Potassium content of bacteria in relation to the minimum $a_{w}$ value which permitted growth. Analyses were performed on organisms grown in basal medium $\left(0.993 a_{w}\right)$ under standard conditions, and the minimum $a_{w}$ values for growth were determined in basal medium adjusted to the desired $a_{w}$ value by addition of sodium chloride. O, Gram-positive cocci; $\boldsymbol{\Lambda}$, Bacillus spp.; $\times$, Gram-negative rods. (1) Regression line for all organisms; (2) regression line excluding data for the most salt-tolerant coccus.

Table 1 shows the concentration gradients of sodium and potassium across the cell boundaries of two cocci which differed greatly in salt tolerance. Internal concentrations were calculated on the basis of $1.50 \mathrm{ml}$. cell water/g. dry wt. It is clear that between strains the internal concentrations of each ion may vary greatly with respect to the external concentration of the same ion and with respect to the internal concentration of the other. 

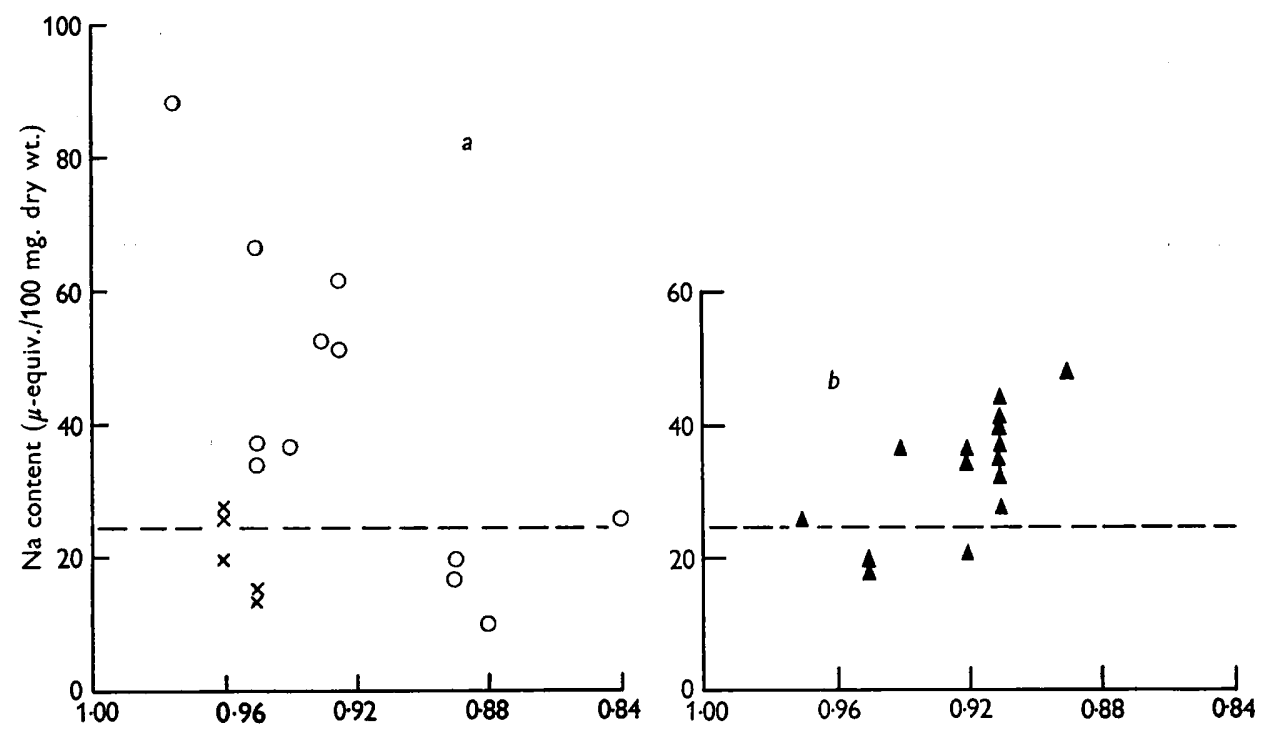

Minimum aw value which permitted growth

Fig. 2. Sodium content of bacteria in relation to the minimum $a_{w}$ value which permitted growth. Conditions as for Fig. 1. The broken line indicates the value at which concentrations of sodium in cells and basal medium were equal. (a) $O$, Gram-positive cocci; $x$, Gram-negative rods. (b) $\dot{\boldsymbol{\Delta}}$, Bacillus spp.

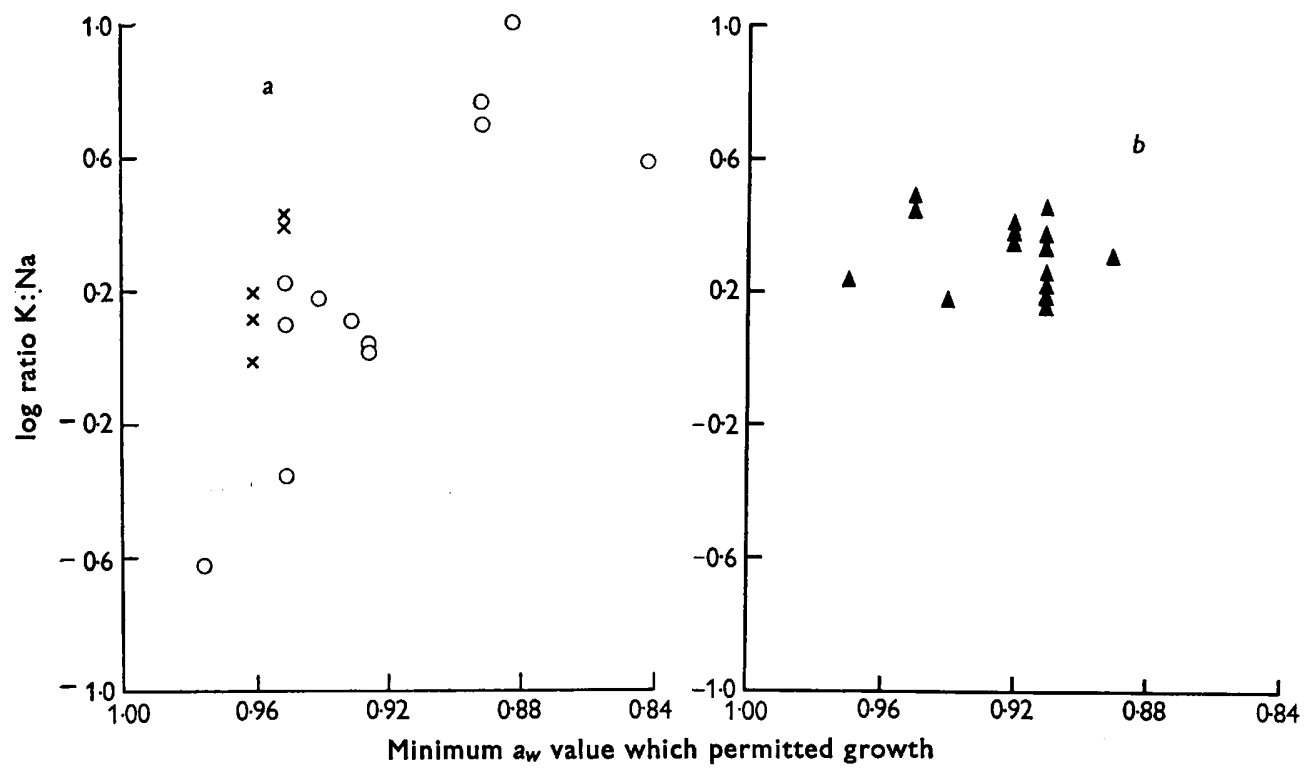

Fig. 3. Logarithms of potassium : sodium ratios in bacteria in relation to the minimum $a_{w}$ values which permitted growth. Conditions as for Fig. 1. (a) O, Gram-positive cocci; $\times$, Gram-negative rods. (b) $\Delta$, Bacillus spp. 
Table 1. Apparent concentrations of sodium and potassium in cocci which differed greatly in salt tolerance

\begin{tabular}{|c|c|c|c|c|c|c|c|c|}
\hline \multirow[b]{2}{*}{ Organism } & \multirow{2}{*}{$\begin{array}{c}\text { Minimum } \\
a_{w} \text { for } \\
\text { growth }\end{array}$} & \multicolumn{2}{|c|}{$\begin{array}{c}\text { Sodium } \\
\text { concentration } \\
(\mathrm{mM})\end{array}$} & \multirow{2}{*}{$\begin{array}{c}\begin{array}{c}\text { Ratio } \\
\text { cell } \mathrm{Na}\end{array} \\
\text { medium } \mathrm{Na}\end{array}$} & \multicolumn{2}{|c|}{$\begin{array}{c}\begin{array}{c}\text { Potassium } \\
\text { concentration } \\
(\mathrm{mM})\end{array} \\
\text { 年 }\end{array}$} & \multirow{2}{*}{$\begin{array}{c}\begin{array}{c}\text { Ratio } \\
\text { cell } \mathbf{K}\end{array} \\
\text { medium } \mathbf{K}\end{array}$} & \multirow{2}{*}{$\begin{array}{r}\text { Ratio } \\
\text { cell K } \\
\text { cell Na }\end{array}$} \\
\hline & & cells* & medium & & cells* & medium & & \\
\hline $\begin{array}{r}\text { Leuconostoc } \\
\text { citrovorum }\end{array}$ & 0.975 & 586 & 163 & $\mathbf{3 \cdot 6}$ & 140 & 25 & $5 \cdot 6$ & 0.34 \\
\hline $\begin{array}{l}\text { Staphylococcus } \\
\text { aureus }\end{array}$ & $0 \cdot 88$ & 64 & 163 & $0 \cdot 39$ & 708 & 25 & $28 \cdot 3$ & $11 \cdot 1$ \\
\hline
\end{tabular}

* Concentrations calculated on the basis of $1.5 \mathrm{ml}$. internal water/g. dry wt. cells.

\section{DISCUSSION}

The correlation observed between potassium content and salt tolerance holds for such a wide range of bacterial strains that it seems likely to be general among nonhalophilic species. However, it must be stressed that this study has been confined to strains growing under one set of environmental conditions. The relationship may not hold for yeasts, since Takada (1956) found that after growth in low-salt medium a yeast adapted to tolerate high salt concentrations contained no more potassium (or sodium) than the parent strain.

The unidentified coccus grew at a sodium chloride concentration above $4 \mathbf{M}$. Such salt tolerance is unusual in a non-halophilic bacterium, and exceeds that of the halophilic Vibrio costicolus (Smith, 1937). The water relations of this coccus deserve further study.

Two assumptions were made in calculating net sodium and potassium contents. The barriers to the movement of sodium, potassium and phosphate were assumed to be identical, and a value of $\mathbf{1 . 5} \mathrm{ml}$. internal water/g. dry wt. was applied in determining interstitial space for all preparations. Insufficient amounts of potassium were present in the interstitial space for the results to be affected appreciably by errors in these assumptions, but estimates of net sodium content might be subject to considerable variation. However, this would not alter the distribution of strains into those containing higher or lower concentrations of sodium than existed in the growth medium, nor would it affect the conclusion that the lowest sodium contents were found in the most salt-tolerant cocci and the least salt-tolerant Bacillus spp. The different relationships between sodium content and salt tolerance in cocci and Grampositive rods suggest that sodium content is not important for salt tolerance in nonhalophilic bacteria. This may be related to the finding that in Salmonella oranienburg maintenance of the internal value for sodium was not dependent on the $a_{w}$ value of the environment, while retention of potassium and of substances which absorbed in the ultraviolet region demanded a relatively low $a_{w}$ value (Christian, 1958), as did retention of amino acids by Escherichia coli (Britten, 1956). The basis of the relationship between potassium content and salt tolerance is obscure. If a high potassium content implies a high concentration of internal solutes, salt-tolerant bacteria will possess low internal $a_{w}$. This property would impart resistance to dehydration and plasmolysis, thus overcoming one of the deleterious effects of a concentrated salt environment. 


\section{REFERENCES}

BARBer, C. (1931). Étude comparative des cendres de certaines éspèces microbiennes. C.R. Soc. Biol., Paris, 106, 982.

BaXTER, R. M. \& Gibbons, N. E. (1956). Effects of sodium and potassium chloride on certain types of Micrococcus halodenitrificans and Pseudomonas salinaria. Canad. J. Microbiol. 2, 599.

BRITTEN, R. J. (1956). Effect of the osmotic strength of the growth medium on the amino acid pool of Escherichia coli. Science, 124, 935.

Cirristian, J. H. B. (1955). The water relations of growth and respiration of Salmonella oranienburg at $30^{\circ}$ C. Aust. J. biol. Sci. 8, 490.

Christian, J. H. B. (1958). The effects of washing treatments on the composition of Salmonella oranienburg. Aust. J. biol. Sci. 11, 538.

Christian, J. H. B. \& ScotT, W. J. (1953). Water relations of salmonellae at $30^{\circ} \mathrm{C}$. Aust. J. biol. Sci. 6, 565.

Mattland, H. B. \& MarTyn, G. (1948). A selective medium for isolating Staphylococcus based on the differential inhibiting effect of increased concentrations of sodium chloride. J. Path. Bact. 60, 553.

Mitchell, P. \& MoYLe, J. (1956). Osmotic function and structure in bacteria. Symp. Soc. gen. Microbiol. 6, 150.

ScotT, W. J. (1953). Water relations of Staphylococcus aureus at $30^{\circ}$ C. Aust. J. Biol. Sci. $6,549$.

Smiтh, F. B. (1937). An investigation of a taint in rib bones of bacon. A determination of halophilic vibrios (n.spp.). Proc. roy. Soc. Qd, 49, 29.

TAKadA, H. (1956). Relation of the external sodium concentration to the sodium influx into the yeast cell adapted to sodium chloride. J. Inst. Polyt., Osaka, D7, 95. 